УДК 343.122

DOI https://doi.org/10.32849/2663-5313/2020.12.32

\title{
Володимир Беньківсъкий,
}

канд. юрид. наук,

асистент кафедри кримінально-правової політики та кримінального права

Інституту права

Київського начіонального університету імені Тараса Шевченка

\section{ОСНОВНІ КОНЦЕПТУАЛЬНІ ПІДХОДИ ТА ПРОБЛЕМИ ПРИЧИННОГО ЗВ'ЯЗКУ В ТЕОРІЇ КРИМІНАЛЬНОГО ПРАВА}

Стаття присвячена комплексному дослідженню основних конщепиій і підходів щодо причинно20 зв'язку у кримінальному праві. Досліджено сутність та обгрунтування уявлень про причинний зв'язок у кримінальному праві як об'єктивної реальності.

Зазначається, що уявлення про причинний зв'язок, що має кримінально-правове значення, як про об'єктивний закладалося ще у межах німеиької кримінально-правової доктрини.

Також автор зазначає, що сучасні уявлення про об'єктивну властивість або характеристику причинного зв'язку були синтезом англійської та німецької кримінально-правової доктрин.

Автор зазначає, що у межах іншого підходу щодо об'єктивності каузальності передбачалося значне теоретичне, методологічне ї̈ обгрунтування, яке мало діалектико-матеріалістичний характер.

Автор наголошує, що певний формально-логічний підхід до розуміння каузального зв'язку у праиях англійських логіків та філософів не виключає уявлення про даний зв'язок як об'єктивний.

Констатується, що новим рівнем розуміння об'єктивної каузальності можна вважати інформачійний підхід. Зокрема, у науковій доктрині України обгрунтовується думка, що існують суттєві відмінності між інформачійними та неінформачійними діяннями; відповідно, існує відмінність причинних зв'язків у межах даних діянь.

Автор звертає увагу на те, що інформачійна причинність (інформачійний причинний зв'язок) не має однозначної наукової характеристики як суто об'єктивна, оскільки діяння в інформачійному просторі так чи інакше передбачає опосередкування усвідомленням (усвідомленою діяльністю суб'єкта).

Особливу увагу автор звертає на таку характеристику у межах спричинення, як можливість (класично-реальна можливість діяння).

3 погляду автора, у кримінальному праві виникають «граничні» ситуачії, коли необхідно акиентувати увагу на значенні суб'єкта (його дї, діяння) у межах прочесу, що породжує (об'єктивно) небезпечні для суспільства наслідки. Відповідно, реальна можливість як результат, на думку автора, усієї суми необхідних ситуачійних чинників може враховуватися у кримінально-правовій оціниі поведінки суб'єкта. Традииійно застосовуване абстрагування від поведінки суб'єкта шляхом застосування поняття «діяння» утруднює, з погляду автора, правову оцінку дій особи.

Автор констатує також наявність значної методологічної і обгрунтувальної бази щодо розуміння причинності і причинного зв'язку як суб'єктивного.

Особливу увагу автор звертає на те, що в умовах формування нового кримінального законодавства України формально можна констатувати виникнення проблеми поділу причинного зв'язку на причинний зв'язок у межах складу кримінального проступку та причинний зв'язок у межах складу злочину.

Ключові слова: причинний зв'язок, кримінальне право, кримінальне законодавство, інформаційна причинність, суб'єктивна причинність, склад злочину, склад кримінально-правового проступку.

Постановка проблеми. Важливість представленої автором проблематики зумовлена необхідністю переосмислення й аналізу основних концепцій і підходів щодо розуміння юридично значущого причинного зв'язку як умови кримінальної відповідальності суб'єкта.

Вибір найбільш обгрунтованого уявлення про причинний зв'язок у криміналь- ному праві - основа точної правової оцінки діяння, вчиненого суб'єктом.

Аналіз останніх досліджень і публікацій $з$ теми. В огляді сучасного стану розроблення проблеми причинності і причинного зв'язку важливими є наукові і доктринальні праці таких авторів, як А.А. Піонтковський, Н.Ф. Кузнєцова, М.Д. Шаргородський, 
Г.А. Крігер, В.М. Кудрявцев, Г.В. Тімейко та ін.

В українській кримінально-правовій доктрині необхідно звернути увагу на роботи таких відомих науковців, як Я.М. Брайнін, А.А. Музика, Н.М. Ярмиш, С.Р. Багіров, О.Л. Тимчук та ін.

За останній час необхідно звернути увагу на праці таких українських вчених щодо проблематики причинного зв'язку в кримінальному праві, як С.В. Бабанін (стаття «Причинний зв'язок як ознака об'єктивної сторони порушення чинних на транспорті правил» 2014 р.), К.В. Катеринчук («Проблеми причинного зв'язку у злочинах проти здоров'я особи» 2017 р.), В.А. Мисливий та ін.

Цілі статті (постановка завдання). У рамках представленого дослідження можна сформулювати такі цілі:

1) визначити основні концептуальні підходи та уявлення про причинний зв'язок;

2) проаналізувати перспективність окремих уявлень про причинний зв'язок в контексті сучасного його розуміння та ефективності застосування в рамках здійснення правової оцінки діянь;

3) звернути увагу на особливі уявлення про причинний зв'язок (інформаційна причинність, фіктивна причинність та ін.) у контексті меж їх застосування у сучасній кримінально-правовій доктрині;

4) врахувати у загальному плані зміни у сучасному кримінальному законодавстві України для визначення перспектив нового розуміння причинного зв'язку (причинний зв'язок у складі кримінального проступку, причинний зв’язок у складі злочину).

Виклад основного матеріалу. Проблематика причинного зв'язку у кримінальноправовій доктрині характеризується рядом не до кінця вирішених питань, які знаходять своє особливе рішення у межах концептуальних підходів, запропонованих юристаминауковцями.

До згаданих проблемних питань, з погляду автора, належать такі:

1) питання про те, чи розглядати причинний зв'язок у кримінальному праві як об'єктивний або як суб'єктивний;

2) питання методики встановлення причинного зв'язку у кримінальному праві;

3) пов'язане 3 п. 2 питання «протяжності» або юридично доцільної компонентності причинного зв'язку (тобто яка кількість складників причинного зв'язку є допустимою у межах кримінального права);

4) проблема ступеня значущості причинного зв'язку у вирішенні питання кримінальної відповідальності особи.
Зазначені питання не вичерпують усієї проблематики причинного зв'язку.

Зокрема, на особливу увагу заслуговують питання «нетипової» каузальності (статистична, інформаційна, винна та ін.). Як вже зазначалося вище, ключовим проблемним питанням каузальності є з'ясування концептуальної дилеми: розглядати причинний зв'язок, що має кримінально-правове значення, як об'єктивний (що існує незалежно від усвідомлення його учасниками кримінально-правових відносин) або як суб'єктивний (зв'язок має кримінально-правове значення, оскільки суб'єкт злочину усвідомлює його розвиток, з точки зору осіб, які здійснюють кримінально-правову оцінку).

Питання об'єктивного причинного зв'язку у науці пов'язується з однорідністю (або одноманітністю) наукових підходів до розуміння даного зв'язку у межах конкретних наук, зокрема у межах кримінального права. Єдине розуміння причинного зв’язку - умова (на думку науковців, що обстоюють позицію об'єктивної каузальності) не утворення конкретно-наукових і значною мірою суб'єктивістських версій причинного зв'язку.

Аналіз проблеми об'єктивної каузальності у кримінальному праві дає змогу говорити про включення причинного зв'язку в об'єктивну сторону складу злочину (кримінального правопорушення); юридичним наслідком визнання об'єктивності причинного зв'язку є його розгляд в об'єктивній частині складу злочину (кримінального правопорушення), виникнення його значення як об'єктивної умови кримінальної відповідальності.

Також уявлення про причинний зв'язок як про об'єктивний у спеціальному аспекті впливає на вирішення питання відповідальності співучасників скоєння злочину, можливо, осіб, причетних до скоєння злочину, якщо йдеться про те, що роль кожного складника злочину у загальному комплексі нерівноцінна на відміну від, зокрема, прийнятої у теорії «conditio sine qua non» повної рівноцінності (але не рівнозначності) всіх попередніх близьких чи віддалених умов його настання [1, с. 258].

Проблематика об'єктивної каузальності з точки зору відомих фахівців у галузі права $\epsilon$ в основному вирішеною, сформованою.

На думку автора представленого дослідження, сформувалися принаймні два підходи щодо проблематики об'єктивної каузальності.

Перший підхід характерний для англійської та німецької школи кримінального права і стосується прагматичного викорис- 
тання властивостей причинного зв'язку (структура, часова характеристика) для обгрунтування кримінальної відповідальності особи.

У межах даного підходу враховується:

1) структура зв’язку («причина-наслідок»);

2) часовий «лаг» між дією причини та настанням суспільно-небезпечних наслідків.

Перший підхід до розуміння об'єктивної каузальності (який можна назвати також «аксіоматичним») є акцентуацією на причинному зв'язку як інструменті правової оцінки поведінки особи, що вчинила (або вчинює) суспільно-небезпечне діяння (злочин, кримінальне правопорушення або кримінальний проступок).

Перший підхід передбачає також певний консенсус відомих науковців (засновників теорій, прийнятих у кримінальному праві, та їх послідовників) щодо об'єктивності причинного зв'язку як базисного посилу для встановлення даного зв'язку. Зокрема, для таких науковців, як М. Бурі, Круг, Глазер та ін., об'єктивність зв'язку не потребувала доведення.

Тобто у межах згаданого підходу до розуміння об'єктивної каузальності існує ії̈ іманентна характеристика «об’єктивність».

Зазначений науковий підхід реалізувався, зокрема, у теорії адекватної причинності (Кріс, Рюмелін), в тій їі частині, де не досліджується суб'єктивне ставлення юриста щодо врахування причинного зв'язку у правовій оцінці (науковий підхід Трегера).

Усі інші теорії (наукові підходи), які «сприйняли» об'єктивність каузальності аксіоматично (теорія причин і умов, головної причини та ін.), є цілісними і не характеризуються «суб'єктивістськими» винятками щодо і у межах визначення юридично значимого причинного зв'язку.

Другий підхід щодо об'єктивності каузальності передбачає теоретичне (значною мірою філософське) її обгрунтування; тобто науковці, що дотримуються другого підходу, вважають, що для застосування причинного зв'язку як об'єктивної межі відповідальності необхідне доктринальне обгрунтування каузальності як такої, що розуміється універсально, не передбачає спеціальних, кримінально-правових винятків.

Необхідно зазначити, що даний підхід реалізувався у рамках протидії «ідеалістичним» (або суб'єктивістським) тенденціям у науці (зокрема, правовій науці).

Даний підхід у науці вибудовувався на таких засадах:

1) на діалектичному підході, або, точніше, на його матеріалістичному аспекті;
2) на логічних характеристиках каузальності (конкретно: логічній характеристиці поняття «причина»).

Необхідно зауважити, що п. 2 тісно пов'язаний $з$ розмежуванням співвідносних у рамках дослідження каузальності і причинного зв'язку понять «причина» та «умова».

Зокрема, у науковій ретроспекції простежується зв'язок між науковими поглядами К. Біндінга, К. Біркмейєра та зазначеного вище, відомого англійського логіка і філософа Д.С. Мілля.

У багатьох кримінально-правових дослідженнях проблематики причинного зв'язку наводиться дефініція Д.С. Мілля щодо причини, яка розглядається як сума умов, позитивних і негативних, узятих разом, сукупність випадковостей різного роду, настання яких незмінно супроводжується наслідком.

Уявлення Мілля щодо умов підтримав К. Біркмейєр; К. Біндінг вважав, що причина виникає тоді, коли виникає перевага позитивних умов над негативними [2].

Але «матеріалістичне» уявлення щодо причин і умов було сприйняте у доктрині кримінального права і полягає у такому:

1) якщо за основу аналізу взаємодії явищ береться поняття «причина», то розглядається такий вид детермінізму, як причинність;

2) якщо за основу аналізу взаємодії явищ береться поняття «умова», то розглядається такий вид детермінізму, як зумовленість явищ;

3) причина породжує явище (у кримінально-правовій інтерпретації - діяння породжує суспільно-небезпечні наслідки);

4) умова створює сприятливе «середовище» (зокрема, інтенсифікує процес) для настання наслідку.

Якщо не враховувати наведені відмінності понять «причина» і «умова», відбувається їх ототожнення; дане ототожнення своїм наслідком має неточність кримінальноправової оцінки поведінки особи.

Представники «матеріалістичного» та об'єктивного підходу до розуміння та обгрунтування каузальності на основі з'ясування сутності і змісту властивості «об'єктивність» звертаються до праць філософів, які застосовували «стихійно-діалектичні» або науково-діалектичні підходи до розуміння причинності.

У цьому зв'язку необхідно виділити філософську оцінку щодо каузальності такого відомого мислителя й науковця, як Л. Фейєрбах (за визначенням марксистів, представник «вульгарно-матеріалістичного» підходу); «матеріалістично» акцентовані наукові підходи щодо розуміння причин- 
ності таких визначних французьких науковців, як Гольбах, Дідро; в англійській філософії необхідно виділити такого науковця, як Т. Гоббс. Певна «логізація» каузального зв'язку у працях Ф. Бекона також, з точкина погляд автора, не виключає уявлення про зв'язок як об'єктивний, матеріальний.

Однак названі науковці у «матеріалістичній» парадигмі об'єктивної каузальності є лише попередниками «об'єктивноідеалістичного» підходу Г.В.Ф. Гегеля, діалектико-матеріалістичних підходів Ф. Енгельса, К. Маркса.

Сформульовані щодо обгрунтування об'єктивної каузальності наукові положення активно використовуються такими фахівцями кримінального права України, як В.О. Беньківський, Н.М. Ярмиш, О.Л. Тимчук, А.А. Музика та ін.

Новим рівнем розуміння об'єктивної каузальності можна вважати «інформаційний» підхід, у межах якого враховуються поняття «інформація», «віртуальність», «кіберсфера» та ін.

Необхідно звернути увагу на те, що проблематикою злочинів у віртуальній сфері займалися такі науковці, як В.П. Бєлєнький, Д.С. Азаров, М.В. Карчевський, М.О. Кравцова, М.В. Плугатир та ін.

Зокрема, необхідно звернути увагу на наукові праці Д.С. Азарова [3], у яких взагалі було поставлене питання щодо концептуальних відмінностей «комп'ютерних» злочинів від інших діянь, передбачених в Особливій частині КК України.

Вищезазначені науковці у зв'язку з кримінально-правовою характеристикою злочинів у комп'ютерній сфері також сформували кримінологічне поняття «кіберзлочинність».

Вищеназвані категорії відображають (при ї осмисленні) намагання науковців розглянути новітні підходи у межах розуміння причинного зв'язку як об'єктивного.

Необхідно акцентувати увагу на тому, що використання категорії «інформація» у поєднанні з парадигмою об’єктивної каузальності для пояснення суспільної небезпечності особливих проявів кримінального правопорушення (злочину, проступку) породжує певну суперечність

Дана суперечність полягає в тому, що інформація сама по собі, без опосередкування свідомістю суб’єкта, не породжує і, отже, не може бути виключно об'єктивним чинником породження (у кримінально-правовому сенсі) результату. Разом із тим науковці, що розглядають інформаційну причинність (зокрема, Н.М. Ярмиш, А.Ф. Парфьонов), не висловлюють застереження щодо її об'єктивності.
Проблематика інформаційної причинності розглядається науковцями без з'ясування «докорінного» питання об'єктивності (або суб'єктивності) причинного зв'язку.

Дана проблематика зводиться такими науковцями, як Г.В. Тімейко, Н.М. Ярмиш (а серед молодих науковців - I.В. Черепанов), до з'ясування механізму інформаційного спричинення.

Також необхідно зазначити, що категорія «інформація» використовується згаданими та іншими науковцями для пояснення механізму спричинення злочинною бездіяльністю.

У зв'язку 3 наведеними аспектами питання інформаційної причинності можна погодитись 3 іншою їі назвою - «мотивуюча причинність» (Г.В. Тімейко).

Використання категорії «інформація», 3 погляду автора, не дозволяє зробити однозначний висновок щодо об'єктивного або суб'єктивного характеру каузальності й причинного зв'язку в кримінальному праві.

Дана неоднозначність визначена самим об'єктивно-суб'єктивним характером інформації.

3 погляду автора, інформаційна причинність, а підкресленням моменту активності - інформаційне спричинення, є об'єктивно-суб'єктивним.

Дане твердження базується, на думку автора, на таких підставах:

1) інформація має (враховуючи матеріальні носії) об'єктивний або зовні об'єктивований характер;

2) зміст інформації (як чинника, що враховується у кримінально-правових оцінках) «опосередковується» свідомістю суб'єкта;

3) «опосередкування» інформації свідомістю суб'єкта (який, відповідно до пропозицій Н.М. Ярмиш, безпосередньо вчинює злочин) перетворює інформацію на дієвий чинник, що заподіює результат, оцінюваний у кримінальному праві;

4) об'єктивно-суб'єктивний характер інформаційної причинності підтверджується різними за характером і змістовим «наповненням» етапами інформаційного спричинення.

Якщо теорія інформаційної причинності розглядає об'єктивність причинного зв'язку як певну «даність», модульовану та включену в інформаційний простір [4, с. 294], то теорія можливості і дійсності може розглядатися як оригінально-науковий спосіб доказування об'єктивності зв'язку через доказування його необхідності.

Необхідно зазначити, що виділення у межах даного наукового дослідження 
інформаційного підходу, а також підходу, заснованого на категоріях «можливість» i «дійсність», обгрунтоване часто виникаючими проблемами, пов'язаними 3 правовою оцінкою «граничних» кримінально-правових ситуацій, злочинів, зв'язок у межах яких $€$ опосередкованим або формується під дією привхідних обставин або для нього існує значний проміжок часу [5, с. 60] щодо настання наслідку діяння.

У філософії традиційно розглядається два різновиди категорії «можливість»:

1) формальна, що взагалі передбачає можливість реалізації процесу, явища;

2) реальна, у межах якої вже додається певна «векторність» або напрям реалізації того або іншого процесу або явища.

Серед науковців, що формували засади причинної теорії можливості і дійсності, традиційно виділяють Т.Л. Сєргєєву, В.С. Прохорова, П.Г. Семенова.

Серед сучасних праць необхідно звернути увагу на наукові узагальнення щодо концепцій причинного зв'язку професора Тарбагаєва А.Н., у яких окреме і важливе місце було також віддане причинній теорії можливості і дійсності.

На думку автора, теорія можливості і дійсності виникла як певна наукова «рефлексія», пов'язана з необхідністю обгрунтування закономірного і необхідного характеру причинного зв'язку у межах кримінально-правової науки.

У межах названої теорії необхідно розглянути такі критерії щодо обгрунтування виникнення закономірного й об'єктивного спричинення:

1) дія (діяння) суб’єкта передує у часі настанню результату;

2) дія (діяння) суб'єкта є одним зі складників - необхідною умовою результату;

3) дія (діяння) суб'єкта утворює реальну можливість настання небезпечного результату [6, с. 379].

3 погляду автора, у кримінальному праві виникають «граничні» ситуації, коли необхідно акцентувати увагу на значенні суб’єкта (його дії, діяння) у межах процесу, що породжує (об'єктивно) небезпечні для суспільства наслідки. Відповідно, реальна можливість як результат, на думку автора, усієї суми необхідних ситуаційних чинників може враховуватися у кримінально-правовій оцінці поведінки суб'єкта. Традиційно застосовуване абстрагування від поведінки суб'єкта шляхом застосування поняття «діяння» утруднює, на думку автора, правову оцінку дій особи.

Особливе місце серед оригінальних підходів щодо об'єктивності (або суб’єктивного характеру) причинного зв'язку займає юридична теорія фіктивної причинності.

За загальним правилом, юридична фікція - правовий прийом, що полягає у припущенні факту поза його дійсністю (дійсною наявністю). Як термін юридична фікція обмежуе [7, с. 184] (у розумінні «визначає») твердження (дефініцію) відносно самого себе.

На думку автора, зазначений підхід (аналіз причинності на основі уявлення про правову фікцію) має право на існування та застосування у такому вузьконауковому сегменті кримінального права, як уявлення про кримінально-правовий, юридично-значущий причинний зв'язок, але при цьому (як буде показано далі) повинні бути дотримані ряд умов або підстав, пов'язаних з аналізом конкретної ситуації.

Питаннями юридичної теорії фіктивної причинності займався такий відомий науковець, як А.В. Федотов; серед інших дослідників даної проблематики варто виділити Є. Григоніса, О. Леонтьєва.

У критичному аспекті теорію фіктивної причинності та доцільність її застосування в межах кримінального права розглядає професор В.Б. Малінін.

Теорія фіктивної причинності детально була розглянута й критично проаналізована згаданим науковцем у четвертому томі колективної наукової праці «Энциклопедия уголовного права» (проф. В.Б. Малінін та ін.).

Треба звернути увагу, що науковий підхід у рамках зазначеної теорії причинності та іï критичної інтерпретації передбачає:

1) застосування юридичної фікції для з'ясування юридично значущого причинного зв'язку у «граничних» ситуаціях;

2) об'єктивний характер причинного зв'язку, по суті, обгрунтовується використанням поняття «достовірність».

«Граничний» характер ситуації пов'язаний з такими особливостями:

1) достовірно та у відносно невизначеній ситуації передбачається суспільно небезпечне заподіяння;

2) є підстави вважати (достовірно встановлено), що у межах діяльності кола осіб існувала певна дія, що може призвести (або призвела) до спричинення шкоди потерпілому.

Класичною (i водночас «граничною» 3 точки зору особливостей кримінальноправової оцінки) є ситуація на полюванні, коли кожен із суб'єктів міг заподіяти шкоду потерпілому в результаті неналежної оцінки зв'язку подій, проявленої недбалості та ін. 
Встановлення юридично фіктивного причинного зв'язку є необхідністю з таких підстав:

1) достовірно встановлене коло суб'єктів і характер їхніх дій;

2) достовірно встановлено, що потерпілому заподіяна шкода;

3) для кримінально-правової оцінки ситуації необхідно припустити існування об'єктивного причинного зв'язку між діями (або можливими діями) одного із суб'єктів та шкодою, завданою потерпілому; як результат (з погляду А.В. Федотова) можливе визначення кола суб'єктів кримінальної відповідальності.

Необхідно підкреслити додатково, що алгоритм дослідження об'єктивності як іманентної характеристики причинного зв'язку у тому числі в рамках юридичної теорії фіктивної причинності полягає в розгляді «граничних» ситуацій, структурною частиною яких $є$ заподіяння й пов'язаними з даним фактом особливостями кримінально-правової оцінки.

Юридичну теорію фіктивної причинності та ряд інших теорій можна охарактеризувати як особливі теорії. Ряд науковців (зокрема, А.І. Коробєєв та ін.) пов'язують згадану особливість з різною юридичною природою суспільно-небезпечних діянь: фізичною, інформаційною, нормативно-програмною.

Розгляд об'єктивності як іманентної характеристики причинного зв'язку у межах «особливих» теорій причинності породжуе ряд проблемних питань, які потребують додаткового наукового дослідження.

Зокрема, об'єктивність каузального зв'язку в теорії інформаційного спричинення можна розглядати (враховуючи механізм спричинення типу «інформаційний сигнал опосередковане його сприйняття суб'єктом (взаємопов'язаними суб'єктами) - дія (невиконання бажаної дії) - злочинний результат») як його приблизну або умовну («прийняту за замовчуванням») характеристику.

3 точки зору автора дослідження, у вищенаведеному випадку можна говорити про об'єктивно-суб'єктивний причинний зв'язок.

У межах причинної теорії можливості і дійсності (яка вважається рядом науковців завершеною і зрозумілою) постає проблема критеріїв «вимірювання» або оцінки реальної можливості спричинення суспільно-небезпечного наслідку. Реальна можливість (а у конкретних юридичних складах - «реальна загроза») повинна стати аргументованою частиною кримінально-правової оцінки у врахуванні особливостей злочинного заподіяння та аналізі характеристик діяння.

Так, на думку доктора юридичних наук P. Вереші, професора M.I. Панова та ін., сус- пільно-небезпечному діянню мають бути властиві неминучість чи реальна можливість настання шкідливого наслідку [8, с. 111].

Що стосується уявлення про суб'єктивну причинність (суб'єктивний причинний зв'язок), то тут наголошувалося і наголошується на обгрунтувальному кримінальному характері усвідомленості зв’язку. Відсутність такого усвідомлення виключала і виключає розгляд причинного зв'язку як умови кримінальної відповідальності суб'єкта.

У цьому зв'язку можна виділити погляди таких науковців, як Е. Гафтер, А. Меркель, які вважали, що суто об'єктивну причинність для юриспруденції не можна вважати прийнятною.

У парадигмі українського кримінального права особливе місце у тому, що стосується розгляду кримінально-правового причинного зв'язку, займає науковий підхід проф. O.M. Костенка; у межах природної правової доктрини характеристика причинного зв'язку, значущого у кримінальному праві як усвідомленого, науковцем вважається необхідною.

Особливо необхідно зупинитись на тому, що уявлення про причинний зв’язок у парадигмі кримінального права України повинні бути уточненими; дане твердження насамперед пов'язане 3 розробкою принаймні у «кримінальній» частині нових законопроектів (проф. М.I. Хавронюк, М.I. Мельник та інші відомі представники кримінального права України) окремо законодавчих характеристик злочинів та кримінально-правових проступків. Тобто йдеться про принаймні формальну констатацію двох типів причинного зв'язку:

1) причинного зв'язку у межах складу кримінального проступку;

2) причинного зв'язку у межах складу злочину.

Аналіз нововиниклої юридичної «реальності» - предмет подальшого і перспективного дослідження у контексті проблематики причинного зв’язку в кримінальному праві.

\section{Висновки}

За результатами проведеного дослідження можна зробити такі висновки:

1) парадигма основних концепцій і підходів щодо розуміння причинного зв'язку в кримінальному праві залишається відносно незмінною;

2) перспективним є дослідження особливих концепцій і підходів щодо розуміння причинного зв'язку в кримінальному праві (теорія інформаційної причинності, фіктивної причинності, спричинення реальної можливості виникнення шкоди та ін.); 
3) необхідно звернути особливу увагу на зміни у праві та законодавстві України, поставивши питання: чи необхідно у межах Загальної частини проектів нових кримінально-правових кодифікованих актів України більш точно визначити і взагалі передбачити законодавче поняття причинного зв'язку;

4) важливою 3 точки зору подальших досліджень є формальна констатація наявності двох типів причинного зв'язку у сучасному кримінальному праві та законодавстві України: причинний зв'язок у складі кримінального проступку (offense) та причинний зв’язок у складі злочину (crime).

\section{Список використаних джерел:}

1. Бабанін С. В. Причинний зв'язок як ознака об'єктивної сторони порушення чинних на транспорті правил. Науковий вісник Дніпропетровсвкого державного університету внутрішніх справ. 2014. № 4. C. 257-263.

2. Binding. Die Normen und ihre Übertretung. Leipzig, 1890. B.I. S. 113 / Цит. по кн.: Шарго- родский М.Д. Избранные работы по уголовному праву. СПб.: Издательство «Юридический центр Пресс», 2003. 434 c.

3. Азаров Д.С. Злочини у сфері комп'ютерної інформації (кримінально-правове дослідження) : монографія. Київ: Атіка, 2007. 304 с.

4. Кримінологія : підручник / В.В. Голіна, Б.М. Головкін, М.Ю. Валуйський та ін. / за ред. В.В. Головкіна, Б.М. Головкіна. Харків: Право, 2014. 449 c.

5. Бережний С.Д. Відповідальність за умисне вбивство з корисливих мотивів за кримінальним законодавством України : монографія. Хмельницький: Хмельницький університет управління та права, 2011. 236 с

6. Полный курс уголовного права : в 5 т. / под ред. докт. юрид. наук, проф., заслуженного деятеля науки РФ А.И. Коробеева. Преступление u наказание. СПб.: Издательство Р. Асланова «Юридический центр Пресс», 2008. Т. 1. 1133 с.

7. Європейський словник філософій: Лексикон неперекладностей. Вінниця: «Дух і Літера», 2013. T. 3. 326 c.

8. Вереша Р.В. Кримінальне право України. Загальна частина. Конспект лекцій : навчальний посібник. Київ: Алерта, 2019. 362 с.

Volodymyr Benkivsky. Basic conceptual approaches and problems in the theory of criminal law

The article is devoted to a comprehensive study of the basic concepts and approaches to causation in criminal law. The essence and substantiation of ideas about causation in criminal law as an objective reality are studied.

It is noted that the notion of causation, which has a criminal-legal significance as an objective one, was established within the framework of German criminal law doctrine.

In particular, the author notes that modern ideas about the objective property or characteristics of causation were a synthesis of English and German criminal law doctrines.

The author notes that another approach to the objectivity of causality provided a significant theoretical, methodological justification, which was dialectical-materialistic in nature.

The author also notes that a certain formal-logical approach to understanding the causal connection in the works of English logicians and philosophers does not exclude the idea of this connection as objective.

The author states that a new level of understanding of objective causality can be considered an in formation approach. In particular, the scientific doctrine of Ukraine substantiates the opinion that there are significant differences between informational and non-informational acts; accordingly, there is a difference in causation within these actions.

The author drawes attention to the fact that information causality (information causation) does not have an unambiguous scientific characteristic as a purely objective one; because, causing in the information space in one way or another involves mediation by awareness (conscious activity of the subject).

The author pays special attention to such a characteristic within the cause as a possibility (classical-real possibility of causing).

From the author's point of view, in criminal law there are «borderline» situations when it is necessary to emphasize the importance of the subject (his actions, deeds) within the process that creates (objectively) dangerous consequences for society. Accordingly, the real possibility as a result, according to the author, of the whole sum of the necessary situational factors can be taken into account in the criminal-legal assessment of the subject's behavior. Traditionally used abstraction from the subject's behavior by applying the concept of «action», complicates, from the point of view of the author, the legal assessment of a person's actions.

The author also states that there is a significant methodological and substantiating basis for understanding causality and causation as subjective.

The author pays special attention to the fact that in the conditions of formation of the new criminal legislation of Ukraine it is possible to formally state the problem of division of causation into causation within the criminal offense and causation within the crime.

Key words: causation, criminal law, criminal legislation, information causality, subjective causality, crime of corpus delicti, offense of corpus delicti. 